\title{
MANGANESE ACCUMULATION AND ITS RELATION TO "EUCALYPTUS SHOOT BLIGHT IN THE VALE DO RIO DOCE"(1)
}

\author{
Fernando Palha Leite ${ }^{(2)}$, Roberto Ferreira Novais ${ }^{(3)}$, Ivo Ribeiro Silva ${ }^{(4)}$, Nairam Félix \\ $\operatorname{Barros}^{(5)}$, Júlio César Lima Neves ${ }^{(4)}$, Alex Giovanny B. Medeiros ${ }^{(2)}$, Marília Contin \\ Ventrella $^{(6)}$ \& Ecila Mercês de Albuquerque Villani ${ }^{(7)}$
}

\begin{abstract}
SUMMARY
Eucalyptus Shoot Blight in the Vale do Rio Doce (ESBVRD) is an anomaly that leads to reduced growth and, in more extreme cases, to death of eucalyptus plants. Initially diagnosed in plantations in the region of the Vale do Rio Doce, in the State of Minas Gerais, Brazil, this problem has also been found in plantations in other regions of the country and even in other countries. Although the symptoms of this anomaly are well-known, its causes are not yet understood. The aim of this study was to evaluate the cause-effect relationship between accumulation of manganese (Mn) in eucalyptus clones and ESBVRD. Characterization of the environment in areas of greater occurrence of this problem in regard to soil, climate and fluctuation of the water table was undertaken in eucalyptus plantations of the Celulose Nipobrasileira S.A. (Cenibra) company in the region of the Vale do Rio Doce. Plant tissues were sampled in two situations. In the first situation, diagnosis occurred in the initial phase of the anomaly in clones with differentiated tolerance to the problem; in the second situation, diagnosis was made in a single clone, considered to be sensitive, in two time periods - in the phase with the strong presence of symptoms and in the recovery phase, in areas of occurrence and in areas of escape from the problem. The most ESBVRD-sensitive clone showed much higher (4.8 times higher) leaf Mn contents than more tolerant clones. In plants with the anomaly, Mn leaf contents were greater than $3,070 \mathrm{mg} \mathrm{kg}^{-1}$, much greater than the quantity found in those without the anomaly $\left(734 \mathrm{mg} \mathrm{kg}^{-1}\right)$. In the period in which the symptoms began to wane, there was a sharp decline in leaf Mn contents, from 2,194 to $847 \mathrm{mg} \mathrm{kg}^{-1}$.
\end{abstract}

\footnotetext{
(1) Received for publication on February 27, 2013 and approved on October 25, 2013.

(2) Researcher, Coordenação de Pesquisa e Desenvolvimento Florestal (GGF-P), Celulose Nipo-Brasileira S.A. - CENIBRA. Regional Rio Doce - MG. Rod. MG 758, km 3, Distrito Perpétuo Socorro. CEP 35196-000 Belo Oriente (MG). E-mail: fernando.leite@cenibra.com.br, alex.medeiros@cenibra.com.br

(3) Emeritus Professor, Universidade Federal de Viçosa - UFV, Campus de Rio Paranaíba. Rod. MG-230, km 7. CEP 38810-000 Rio Paranaíba (MG). Senior Researcher Fellowship (CAPES). E-mail: rfnovais@ufv.br

(4) Adjunct Professor, Soil Department - DPS, Universidade Federal de Viçosa - UFV. Av. P.H. Rolfs, s/n. CEP 36570-900 Viçosa (MG). E-mail: ivosilva@ufv.br; julio_2003@yahoo.com.br

(5) Full Professor, DPS/UFV. E-mail: nfbarros@ufv.br

(6) Adjunct Professor, Plant Biology Department, UFV. E-mail: ventrella@ufv.br

(7) Posdoctoral student, DPS/UFV. FAPEMIG Fellowship (Processo CAG-21006/09). E-mail: ecilavillani@hotmail.com
} 


\begin{abstract}
Manganese content in the above ground part and plant litter $\left(44.4 \mathrm{~g} \mathrm{ha}^{-1}\right)$ in the area of occurrence of the anomaly was three times greater than that found in these same components (14.1 $\left.\mathrm{g} \mathrm{ha}^{-1}\right)$ in the area of absence of the symptom. Based on the evidence found, such as the existence of environmental conditions favorable to high Mn availability to the plants in the areas of greatest incidence of ESBVRD, greater uptake of Mn in sensitive clones and in plants with symptoms, and a synchronism between the intensity of symptoms of ESBVRD and leaf Mn contents, it may be inferred that temporary excess of Mn in eucalyptus plants is closely related to ESBVRD.
\end{abstract}

Index terms: hypoxia, groundwater, redox potential.

\title{
RESUMO: ACÚMULO DE MANGANÊS EM PLANTIOS DE EUCALIPTO E SUA RELAÇÃO COM A "SECA DE PONTEIROS DO EUCALIPTO DO VALE DO RIO DOCE"
}

A Seca de Ponteiros do Eucalipto do Vale do Rio Doce (SPEVRD) é uma anomalia que leva à redução do crescimento e, em casos mais extremos, à morte dessa cultura. Inicialmente diagnosticada em plantios localizados na região do Vale do Rio Doce, no Estado de Minas Gerais, Brasil, esse problema também tem sido encontrado em plantios localizados em outras regiões do País e, até mesmo, em outros países. Apesar de os sintomas dessa anomalia serem bem conhecidos, ainda não existe a compreensão das causas desses. O objetivo deste trabalho foi avaliar a relação causa-efeito entre o acúmulo de manganês (Mn) em clones de eucalipto e a SPEVRD. A caracterização do ambiente em áreas de maior ocorrência do problema quanto a solo, clima e flutuação do lençol freático foi realizada em plantios de eucalipto da Empresa Celulose Nipo-brasileira S.A. - Cenibra, na região do Vale do Rio Doce. Foram amostrados tecidos de plantas em duas situações. Na primeira, a diagnose aconteceu na fase inicial da anomalia em clones de tolerância diferenciada do problema; e, na segunda, a diagnose foi realizada em um único clone, considerado sensível, em duas épocas, na fase com a presença de sintomas fortes e na de recuperação, em áreas de ocorrência e de escape do problema. O clone mais sensivel à SPEVRD apresentou teores de Mn nas folhas bem mais elevados (4,8 vezes maior) do que clones mais tolerantes. Em plantas com a anomalia, os teores foliares de $\mathrm{Mn}$ foram superiores a $3.070 \mathrm{mg} \mathrm{kg}^{-1}$, bem maiores do que o valor encontrado naquelas sem anomalia (734 $\mathrm{mg} \mathrm{kg}^{-1}$ ). No período em que os sintomas começam a desaparecer, há queda acentuada nos teores foliares de $\mathrm{Mn}$, passando de 2.194 para $847 \mathrm{mg} \mathrm{kg}^{-1}$. O conteúdo de $\mathrm{Mn}$ na parte aérea e serapilheira $\left(44,4 \mathrm{~g} h \mathrm{a}^{-1}\right)$ na área de ocorrência da anomalia foi três vezes maior ao encontrado nesses mesmos componentes (14,1 $\left.\mathrm{g} \mathrm{ha}^{-1}\right)$, na área de ausência do sintoma. A partir das evidências encontradas como a existência de condições ambientais que favorecem elevada disponibilidade de Mn para as plantas nas áreas de maior incidência da SPEVRD, a maior absorção de Mn em clones sensiveis e em plantas com sintomas, e um sincronismo entre a intensidade dos sintomas da SPEVRD e os teores foliares de Mn, pode-se inferir que o excesso temporário de Mn nas plantas de eucalipto está intimamente relacionado à SPEVRD.

Termos de indexação: hipoxia, lençol freático, potencial redox.

\section{INTRODUCTION}

The region of the Vale do Rio Doce in Minas Gerais was one of the first to undertake commercial planting of eucalyptus in Brazil.

One of the responses of eucalyptus to the edaphic and climatic conditions of this region is an anomaly known as Eucalyptus Shoot Blight in the Vale do Rio Doce (ESBVRD) (Seca do Ponteiro do Eucalipto do Vale do Rio Doce ) or Rio Doce Disease (Mal do Rio Doce) (Doughty, 2000), the cause of which is still unknown. This anomaly is more common in plantations established in regions with altitudes from 200 to $350 \mathrm{~m}$ and mean annual temperatures greater than $23^{\circ} \mathrm{C}$, and it is more intense in soils located at the bottom of valleys Cambissolos (Cambisols) and in soils of alluvial origin Neossolos Flúvicos (Fluvisol), where frequently there are temporary drainage problems. When rainfall in the rainy period is higher, the problem also occurs in plantations located on the lower third of hillsides, and may even reach the middle third and tip (soils without drainage problems).

Plants with this anomaly exhibit typical symptoms, such as darkening at the base of the secondary branches and petioles, which evolves into small lesions at these locations. In this phase, which generally occurs in the months of February to April, there is also shriveling of the leaves. In the months 
from May to June, these symptoms intensify, the leaves exhibit a leathery and rougher texture (callosing of the lower surface), and they become brittle and shriveled up, followed by drying out and abscission (in a short period of time). The branches exhibit small cankers - small cracks predominant at the base of the secondary branches and bases of the petioles. In July, in addition to stronger symptoms, there is also leaf abscission. In August to September, the plants continue to exhibit strong symptoms and there is also the beginning of recovery (appearance of budding over the trunk surface, generally with the presence of bifurcations on the apical part). The symptoms begin in the regions near the shoots (older leaves), causing loss of growth and even death of the plants in more extreme cases. Trees that survive may have total or partial drying out of their shoots, loss of dominance and the appearance of budding over the surface of the trunk during the recovery period (Ferreira, 1986).

Symptoms similar to those observed in the initial phases of the appearance of this anomaly have also been observed in plantations located in diverse regions of the Vale do Rio Doce and in other regions of Brazil (Pará, Maranhão, Bahia, São Paulo, Paraná) and also in other countries (Uruguay and Venezuela). Over the rotation period, more severe symptoms are observed in plantings from 12 to 24 months of age; however, at ages greater than 24 months, symptoms also appear, but generally of lesser intensity as of the fourth year.

Some possible causes for ESBVRD, such as phytopathogens, atmospheric pollution and nutritional deficiency, have not been proven (Dianese et al., 1984). Ferreira (1986) comments that among the causes of ESBVRD are high levels of $\mathrm{Fe}$ and $\mathrm{Mn}$ in the plant tissues, especially in periods of deficiency of $\mathrm{O}_{2}$ (hypoxia), followed by a drought period.

Under the hypoxia condition, there may be alterations in soil chemical characteristics, like $\mathrm{pH}$ and redox potential (Eh). According to Abreu et al. (2007), in soils with deficient drainage, compacted soils and those with $\mathrm{pH}$ values less than 5.5, Mn contents in the soil may reach levels which are toxic to plants. Studies show a close relationship between the Eh changes of flooded soils and plant metabolism, due to the increase in availability of ions such as $\mathrm{Mn}, \mathrm{Fe}$ and $\mathrm{Cu}$ (Hauck et al., 2003; Dat et al., 2004; Shenker et al., 2004). Under conditions of excess Mn, there may be a decrease in uptake of other cations $(\mathrm{Ca}, \mathrm{Fe}$ and $\mathrm{Mg}$ ) and in the photosynthetic rate, and an increase in the activity of antioxidant enzymes, among them, superoxide dismutase (SOD), catalase and peroxidases (Wang et al., 2009; Mou et al., 2011). The increase in activity of peroxidase in some species is followed by the appearance of brown lesions, given the oxidation of substrates by this enzyme. The examination of these lesions on common bean leaves showed the presence of phenolic compounds oxidized on the cell wall (Wissemeier \& Horst, 1992). Ernani (2009) reports that in soils with very low $\mathrm{pH}$ and/or with insufficiency of $\mathrm{O}_{2}$ in poorly drained soils, the symptom of $\mathrm{Mn}$ toxicity in apple trees is characterized by splitting in the bark of the main trunk and of the lateral branches; upon removing the bark, dark points are observed in the woody trunk tissue.

According to results obtained by Lacerda et al. (2010) in evaluation of the behavior of eucalyptus clones with differential tolerance to ESBVRD in a nutritional solution with increasing rates of $\mathrm{Mn}$, it was observed that the tolerant clone accumulated much more $\mathrm{Mn}$ in the root system than the sensitive clone and, at the end of the experiment, symptoms appeared which indicated phytotoxicity of Mn at the higher rate $\left(90 \mathrm{mg} \mathrm{L}^{-1}\right)$ in younger leaves of the more sensitive clone.

In this context, the aim of this study was to evaluate the cause-effect relationship between the accumulation of $\mathrm{Mn}$ in eucalyptus clones and ESBVRD.

\section{MATERIALS AND METHODS}

Information in regard to soils of areas with or without incidence of the anomaly in the region of the Vale do Rio Doce (Figure 1) in Minas Gerais in the municipalities of Santana do Paraíso (latitude $19^{\circ} 22^{\prime} 01^{\prime}$; longitude $42^{\circ} 33^{\prime} 03^{\prime \prime}$ ) and Belo Oriente (latitude $19^{\circ} 13^{\prime} 04^{\prime \prime}$; longitude $\left.42^{\circ} 30^{\prime} 00^{\prime \prime}\right)$ were obtained based on analysis of samples collected in profiles up to the depth of 180 $\mathrm{cm}$. For the areas with high incidence, data were used from two profiles in an area of Cambissolo (Cambisol) at the bottom of the valley and from three profiles in an area of Neossolo Flúvico (Fluvisol). To characterize areas of lower incidence, data from 15 profiles of Latossolos (Oxisols) were used.

In one of the areas where sampling was made for nutritional diagnosis, samplings were also performed for chemical characterization of soil from the $0-20$ and 80-100 cm depth layers, in areas with plants with and without ESBVRD symptoms. The following items were determined in these samples: $\mathrm{pH}\left(\mathrm{H}_{2} \mathrm{O}\right)$; exchangeable $\mathrm{Ca}, \mathrm{Mg}$ and $\mathrm{Al}$, extracted with $\mathrm{KCl}$ $1 \mathrm{~mol} \mathrm{~L}^{-1}$; P, K, Na, Zn, Fe, Mn and $\mathrm{Cu}$, by the Mehlich-1 extractor; organic C, by oxidation of organic matter by the Walkley-Black method, and $\mathrm{FeO}_{3}$ and $\mathrm{MnO}$ contents in extracts obtained through sulfuric acid treatment (Embrapa, 1997).

Characterization of the climate of the region where the problem is more severe and what is considered the escape region was made from data collected in weather stations in these regions (Table 1).

Every two weeks, the behavior of the water table was monitored in areas with low, medium and high incidence of ESBVRD over a seven-year period (from October 2002 to December 2009). In the areas with low and medium incidence, there were two monitoring locations and, in the area of high incidence, five 


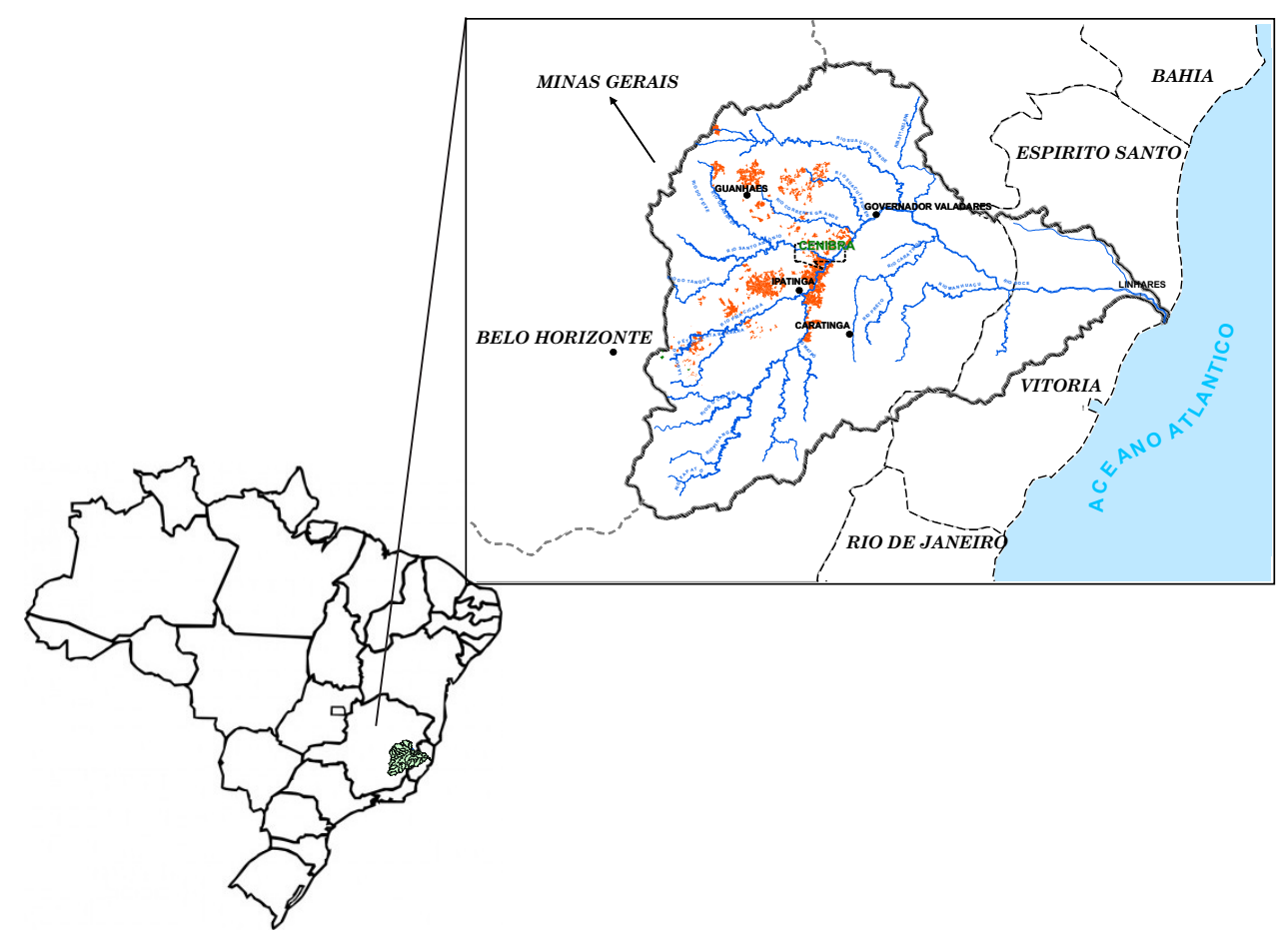

Figure 1. Localization in the region of the Bacia do Rio Doce, MG, Brazil.

Table 1. Climate characteristics of regions with high incidence and low incidence of ESBVRD

\begin{tabular}{|c|c|c|c|c|c|c|c|c|c|}
\hline \multirow{2}{*}{ Location } & \multicolumn{3}{|c|}{ Temperature } & \multirow{2}{*}{$\mathbf{R H}$} & \multirow{2}{*}{ VPD } & \multirow{2}{*}{ ETO } & \multirow{2}{*}{ Radiation } & \multicolumn{2}{|c|}{ Rainfall } \\
\hline & Max. & Mín. & Mean & & & & & Annual & Nov. to Mar. \\
\hline & 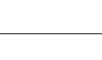 & $-{ }^{\circ} \mathrm{C}-$ & 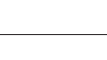 & $\%$ & $\mathrm{hPa}$ & $m m$ dia $^{-1}$ & $\mathrm{mmol} \mathrm{m} \mathrm{m}^{-2} \mathrm{~s}^{-1}$ & $\longrightarrow$ & $\mathrm{mm} \longrightarrow$ \\
\hline Region with low incidence & 24.1 & 15.9 & 20.0 & 74.1 & 3.44 & 2.63 & 15.2 & 1.375 & 1.079 \\
\hline Region with high incidence & 29.5 & 18.9 & 23.8 & 71.3 & 4.80 & 3.13 & 17.4 & 1.307 & 1.023 \\
\hline
\end{tabular}

RH: relative humidity; VPD: vapor pressure deficit; ETO: evapotranspiration.

locations. Chemical characterization of the solution in the water table at these locations and of a stream located less than $100 \mathrm{~m}$ from the monitored area was also made throughout this period in quarterly collections and analyses.

In the period from 1993 to 2010 , areas of occurrence of ESBVRD were monitored in commercial eucalyptus plantations from 12 to 24 months of age in the region of the Vale do Rio Doce. The total area monitored annually was approximately 10,000 ha. The criteria used for identification of symptoms were those proposed by Ferreira (1986). The purpose of this monitoring was to identify patterns of behavior between incidence of the anomaly and the rainfall which occurred in this period.

Anatomical analysis of plant tissues of a clone sensitive to ESBVRD was also carried out under two conditions, of materials originating from the area of occurrence and from the area considered as an escape from the anomaly. Analyses of woody trunk tissue (greatest diameter trunk), young stems, petioles and leaves of a sensitive clone (clone 386) were also carried out at different times of the year (in months before, during and after the appearance of ESBVRD).

Young leaves and stems were fixed in $\mathrm{FAA}_{50}$ for $24 \mathrm{~h}$ and stored in $70 \%$ ethanol (Johansen, 1940), and samples of approximately $0.25 \mathrm{~mm}^{2}$ were dehydrated in an ethanol dehydration series and included in methacrylate (Historesin-Leica). The embedded material was sectioned crosswise and longitudinally in a rotary microtome at a thickness of $5 \mu \mathrm{m}$ and stained with toluidine blue (O'Brien et al., 1964) for metachromasia, and mounted in synthetic resin (Permount).

The trunks of greatest diameter were kept in a well-ventilated place and sectioned crosswise and longitudinally in a sliding microtome at $20 \mu \mathrm{m}$ after boiling in water. The cross sectioning of the trunks (woody trunk tissue) were performed in the region of the medulla to the cambial zone, so as to follow the formation of the growth rings. The sections were clarified with $20 \%$ sodium hypochlorite, stained with 
$1 \%$ safranin, dehydrated in ethanol/xylene series and mounted in synthetic resin (Entelan). Based on the slide collection, digitalized images were obtained of the different organs, both healthy and with lesions and/or changes arising from ESBVRD, on a photomicroscope (Olympus AX70), with the U-photo system.

The nutrient contents in tree tissues were determined in two situations:

1) leaf analysis of two clones (one sensitive clone, clone 1215 , and another of intermediate resistance to ESBVRD, clone 129) in the initial phase of appearance of the anomaly in the month of February. For that purpose, two trees of each clone were sampled, collecting leaf samples from three positions in the canopy (lower, middle and upper third) and from three positions on the branch (nearer to the trunk, intermediate position and more at the tip). The area of this plantation [Neossolo Flúvico (Fluvisol) in the municipality of Santana do Paraíso, MG] was the same area where the level of the water table was monitored, in a region considered to have a high incidence of the anomaly;

2) analysis of the components of the above ground part and root system of a single clone (clone 386 ) in two locations (lower third of the hillside, high incidence area, and upper third of the hillside, low incidence area, with a distance between the two sampling areas of approximately $150 \mathrm{~m}$ ), at two time periods (during manifestation of symptoms and during the beginning of plant recovery) in a year with above normal rainfall (a year favorable to occurrence of ESBVRD). In sampling undertaken in the period of greater incidence of the anomaly, two trees were sampled in each situation. Leaf samples were collected from three positions in the canopy (lower, middle and upper third) and from two positions on the branches (between the trunk and half the length of the branches and from the middle of the branches up to the extremity) and at the main tip. Sampling of the branches followed the criterion used for the leaves, except for collection of shoots at the tip, which was not done. For woody trunk tissue and bark, samples were collected from the lower, middle and upper thirds of the trunk. Samples of plant litter and of roots (fine, medium and thick) at the depths of $0-20$ and $80-100 \mathrm{~cm}$ were also collected. In sampling performed in the recovery period of the plants, three trees in each situation (area with anomaly and area without anomaly) were sampled. In this sampling, branch sections at the base of the secondary branches (locations of greatest occurrence of blight symptoms) and of sections with little incidence of symptoms (segments of branches between the bases of secondary branches) were also collected.

All plant matter samples were dried until constant weight, ground and mineralized. In the extracts from nitric-perchloric digestion, $\mathrm{P}$ was determined by colorimetry; $\mathrm{K}$, by photometry; and $\mathrm{Ca}, \mathrm{Mg}, \mathrm{Zn}, \mathrm{Fe}$, $\mathrm{Mn}$ and $\mathrm{Cu}$ by atomic absorption spectrophotometry.
$\mathrm{N}$ was determined by the Kjeldahl method (Nelson \& Sommers, 1973). B was determined by colorimetry, using curcumin as an indicator, after mineralization of the samples by calcination and dissolution in $\mathrm{HCl} 0.1 \mathrm{~mol} \mathrm{~L}^{-1}$ (Vitti et al., 1997).

The significance of the differences between the $\mathrm{Mn}$ contents in each one of the components of the above ground part, roots and plant litter, in plants with high and low incidence of ESBVRD, was evaluated by the $F$ test after breakdown of the degrees of freedom of the interaction of the treatments of analysis of variance, adopting a level of significance of up to $10 \%$. This analysis was also used to evaluate the differences between leaf contents from clones susceptible to and moderately tolerant to ESBVRD. Data from the program Statistica (Statsoft, 2012) were used for processing.

\section{RESULTS AND DISCUSSION}

The conditions observed in the environments where the ESBVRD is most frequent and intense are characterized by soils with high available Mn contents (Table 2), low pH (Table 3), and a great rise in the level of the water table in the rainiest periods of the year (Figure 2), which favor the formation of a reducing environment (hypoxia). High concentrations of $\mathrm{Mn}$ in the solution of the water table (Table 4) indicate that during the period of greatest rainfall (months of November to January) there is large availability of $\mathrm{Mn}$ in the environment, with potential of being taken up by plants at toxic levels (Colmer \& Voesenek, 2009). These results corroborate Sousa et al. (2009) in stating that reduction of the $\mathrm{Mn}^{4+}$ to $\mathrm{Mn}^{2+}$ in flooded soils may lead to an increase in its concentration in the soil solution, even if the flooding occurs in a short period of time, and that this increase may vary due to the concentration of $\mathrm{Mn}$ and the organic matter content of the soil and, furthermore, due to the soil class.

The data from annual monitoring of the percentage of areas with incidence of the anomaly carried out in the period from 1993 to 2010 in eucalyptus plantations at 12 to 24 months of age (age at which the anomaly is manifested with greatest intensity), indicated that the percentage of the area of trees with symptoms came to $10.5 \%$ of the area monitored in 2002 . Mean rainfall in the period from 1993 to 2009 was $1,136 \mathrm{~mm}$. In the years when the percentage of the area with symptoms remained below $4.5 \%$, rainfall was $1,062 \mathrm{~mm}$ and, in the years when it was above $4.5 \%$, the mean was $1,313 \mathrm{~mm}$.

Analyzing the profile of fluctuation of the level of the water table in the period from 2002 to 2009 (Figure 2) and relating its behavior to the percentages of area with incidence of the anomaly, it was observed that the years of greatest incidence, 2005 (5.6\%), 2007 
(7.4\%) and 2009 (4.7\%), were characterized by periods (beginning as of the months of October or November of the previous year) in which the level of the water table was less than $2.0 \mathrm{~m}$ from the surface for a continuous period greater than three months. Under these conditions, part of the root system remained in a low aeration environment (hypoxia).

Plants at an age of less than 10 months did not show symptoms of ESBVRD, probably through the fact of the root system being more at the surface, still

Table 2. Available $\mathrm{Mn}$ and $\mathrm{Fe}$ (Mehlich-1) and $\mathrm{MnO}$ and $\mathrm{FeO}_{3}$ (total forms) contents in soils where eucalyptus shows high incidence of ESBVRD (Cambisols at the bottom of the valley and Fluvisols) and low incidence of this anomaly (Oxisols)

\begin{tabular}{|c|c|c|c|c|}
\hline Soil $^{(1)}$ & $\mathbf{F e}$ & Mn & $\mathrm{FeO}_{3}$ & $\mathrm{MnO}$ \\
\hline Cambisols at the bottom of the valley & 31.2 & 28.5 & 8.1 & 138.4 \\
\hline Fluvisols & 18.7 & 24.3 & 5.8 & 267.7 \\
\hline Oxisols & 47.9 & 2.4 & 10.3 & 63.5 \\
\hline
\end{tabular}

${ }^{(1)}$ Mean values of the $1-180 \mathrm{~cm}$ depth layer.

Table 3. Properties of the soil in areas where eucalyptus plants were sampled with high or low incidence of ESBVRD symptoms

\begin{tabular}{|c|c|c|c|c|}
\hline \multirow{3}{*}{ Property } & \multicolumn{4}{|c|}{ Incidence } \\
\hline & High & Low & High & Low \\
\hline & Lower third of hillside & Tip & Upper third of hillside & Tip \\
\hline & \multicolumn{2}{|c|}{$0-20 \mathrm{~cm}$} & \multicolumn{2}{|c|}{$-80-100 \mathrm{~cm}-$} \\
\hline $\mathrm{pH}\left(\mathrm{H}_{2} \mathrm{O}\right)$ & 4.50 & 4.40 & 4.40 & 4.20 \\
\hline $\mathrm{MO}^{(1)}, \mathrm{mg} \mathrm{dm}^{-3}$ & 3.30 & 2.90 & 0.70 & 0.90 \\
\hline $\mathrm{P}^{(2)}, \mathrm{mg} \mathrm{dm}^{-3}$ & 7.60 & 1.70 & 0.80 & 0.30 \\
\hline $\mathrm{K}^{(2)}, \mathrm{mg} \mathrm{dm}^{-3}$ & 45.40 & 23.90 & 6.40 & 7.80 \\
\hline $\mathrm{Na}^{(2)}, \mathrm{mg} \mathrm{dm}^{-3}$ & 6.30 & 4.40 & 2.90 & 1.00 \\
\hline $\mathrm{Ca}^{2+(3)}, \mathrm{cmol}_{\mathrm{c}} \mathrm{dm}^{-3}$ & 1.50 & 0.80 & 0.24 & 0.09 \\
\hline $\mathrm{Mg}^{2+(3)}, \mathrm{cmol}_{\mathrm{c}} \mathrm{dm}^{-3}$ & 0.29 & 0.16 & 0.06 & 0.04 \\
\hline $\mathrm{Al}^{3+(3)}, \mathrm{cmol}_{\mathrm{c}} \mathrm{m}^{-3}$ & 0.95 & 1.24 & 1.39 & 1.46 \\
\hline $\mathrm{SB}, \mathrm{cmol}_{\mathrm{c}} \mathrm{dm}^{-3}$ & 1.93 & 1.05 & 0.32 & 0.16 \\
\hline Effective CEC, $\mathrm{cmol}_{\mathrm{c}} \mathrm{dm}^{-3}$ & 2.88 & 2.28 & 1.71 & 1.61 \\
\hline $\mathrm{m}, \%$ & 3.44 & 56.8 & 81.10 & 90.40 \\
\hline $\mathrm{Zn}^{(2)}, \mathrm{mg} \mathrm{dm}^{-3}$ & 1.29 & 0.34 & 0.23 & 0.09 \\
\hline $\mathrm{Cu}^{(2)}, \mathrm{mg} \mathrm{dm}^{-3}$ & 0.90 & 0.06 & 0.77 & 0.07 \\
\hline $\mathrm{Fe}^{(2)}, \mathrm{mg} \mathrm{dm}^{-3}$ & 53.00 & 41.80 & 6.80 & 10.20 \\
\hline $\mathrm{Mn}^{(2)}, \mathrm{mg} \mathrm{dm}^{-3}$ & $45.0 \mathrm{o}$ & 5.10 & 9.50 & 0.30 \\
\hline $\operatorname{Prem}^{(4)}, \mathrm{mg} \mathrm{dm}^{-3}$ & 30.30 & 26.90 & 12.90 & 19.90 \\
\hline
\end{tabular}

(1) Soil organic matter; ${ }^{(2)}$ Mehlich-1 extractor; ${ }^{(3)} \mathrm{KCl} 1 \mathrm{~mol} \mathrm{~L}{ }^{-1}$ extractor; ${ }^{(4)}$ Prem: remaining P (Alvarez V. et al., 2000); SB: sum of bases $\left(\mathrm{Ca}^{2+}+\mathrm{Mg}^{2+}+\mathrm{K}^{+}\right)$; m: Al saturation.

Table 4. Chemical characteristics of stream water and water from the soil water table solution of areas with great incidence of ESBVRD

\begin{tabular}{|c|c|c|c|c|c|c|c|c|c|c|c|c|}
\hline Location $^{(1)}$ & $\mathbf{p H}$ & $\mathrm{EC}^{(2)}$ & $\mathbf{N}$ & $\mathbf{P}$ & $\mathbf{K}$ & $\mathrm{Na}$ & $\mathbf{C a}$ & Mg & $\mathrm{Zn}$ & $\mathrm{Cu}$ & $\mathrm{Fe}$ & Mn \\
\hline & & $\mathrm{mS} \mathrm{cm}^{-1}$ & & & & & $-\mathrm{m}$ & & & & & \\
\hline Stream & 7.4 & 1.45 & 1.86 & 0.06 & 2.37 & 5.43 & 3.66 & 1.14 & 0.01 & 0.01 & 0.31 & 0.07 \\
\hline Water table & 6.2 & 0.12 & 2.83 & 0.24 & 4.45 & 6.93 & 3.90 & 2.34 & 0.15 & 0.02 & 0.20 & 0.26 \\
\hline
\end{tabular}

(1) Mean values of samples collected in the years from 2003 to 2009 (four samples per year). ${ }^{(2)}$ Electrical conductivity. 


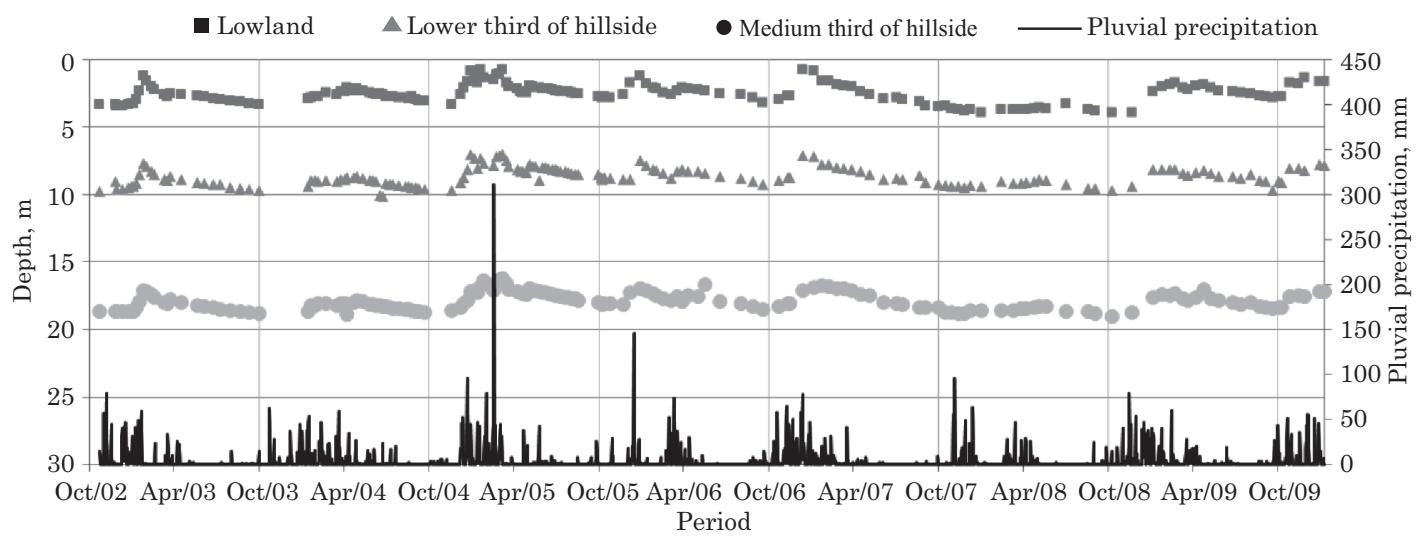

Figure 2. Depth of the water table of points monitored in three topographical positions: lowland (area of high incidence of ESBVRD); lower third of hillside (area of medium incidence), and middle third of the hillside (area of low incidence of the blight) (during the period from October 2002 to December 2009) and rainfall over this period. Planting of eucalyptus in the monitored area was carried out in October 2001 and cutting of the area in July 2009.

distant from the level that the water table may reach in the rainiest years. In contrast, the phase when the symptoms are more common, from 12 to 24 months, is the same in which the leaf area index reaches its maximum point in eucalyptus plantations in the region. The initial rhythm of eucalyptus growth in this region (up to 24 months) is very high in the rainy period, with volumetric growth from the months of December to February of 15 to $20 \mathrm{~m}^{3}$ of wood at 24 months of age, with a mean rate near $6.0 \mathrm{~m}^{3} \mathrm{ha}^{-1} \mathrm{month}^{-1}$ in these months of the year. As of March, the water deficit period begins; in this period (March to May), the growth rate is quite reduced in relation to the previous period, with a mean rate of $2.5 \mathrm{~m}^{3} \mathrm{ha}^{-1}$ month $^{-1}$. In the months of February to April, mean temperatures in the region are quite high, a conditions which also favors $\mathrm{Mn}$ toxicity in the plants (Marschner, 2012).

Diagnosis of the nutritional state of the eucalyptus under different conditions showed that uptake of $\mathrm{Mn}$ reflects variations in the availability of this nutrient in the soil throughout the year, directly in line with the greatest soil moisture conditions (condition for hypoxia) in the region utilized by the root system. In the first situation diagnosed, analyses were made in two genetic materials, one clone of $E$. grandis (clone 129), considered moderately tolerant to ESBVRD, and one hybrid clone (E. grandis vs E. urophylla clone 1215), considered susceptible. In the initial period of appearance of symptoms, there were higher leaf contents of $\mathrm{Mn}$ in the clone considered sensitive as compared to the moderately tolerant material (clone 129) (Table 5). The leaf contents of $\mathrm{Mn}$ were greater in the branches of the lower third of the canopy and those located more at the base of the stems, indicating low mobility of this nutrient in eucalyptus plants (Gonçalves \& Valeri, 2001). The first symptoms of ESBVRD also occurred in the oldest leaves of the plant, as reported by Ferreira (1986).
In the other situation in which diagnosis was also made, carried out in plants in two locations of the cropped area (lower third of the hillside, location of occurrence of the problem, and upper third of the hillside, location considered as an escape region), approximately $150 \mathrm{~m}$ distant from one another, with a clone sensitive to ESBVRD (clone 386), in the month of July (period with the presence of intense symptoms and with leaf loss), leaf contents of Mn much higher in the plants collected in the area of occurrence of the anomaly were observed (Table 6). This same behavior between locations was observed for other components of the above ground part, in the plant litter and in the roots (Table 6). Another sampling carried out in this same location in the recovery period of the plants (month of October) showed a great reduction in $\mathrm{Mn}$ contents, especially in the plants located in the area of high incidence of the problem (Table 7). These results also indicate that the time for carrying out sampling is fundamental for correct diagnosis of the nutritional state of the plants in relation to $\mathrm{Mn}$.

In the samples of branch sections collected nearer to the bases of secondary branches (region with great occurrence of ESBVRD symptoms), the Mn contents in the recovery period were $790 \mathrm{mg} \mathrm{kg}^{-1}$, while in the sections of these same branches without the bases of the secondary branches, the contents found were $571 \mathrm{mg} \mathrm{kg}^{-1}$. This situation indicates greater accumulation of $\mathrm{Mn}$ in the sections where the symptoms are more evident. These regions (branch connecting points) are considered to be points of greatest restriction of water transport in the trees (Hinckley et al., 1991).

The Mn content in the above ground part and plant litter $\left(44.4 \mathrm{~g} \mathrm{ha}^{-1}\right)$ in the area of occurrence of the anomaly was three times greater (Table 8) than that found in these same components $\left(14.1 \mathrm{~g} \mathrm{ha}^{-1}\right)$ in the area of absence of the symptom. In the woody trunk 
Table 5. Leaf Mn contents in eucalyptus plants (clone with intermediate tolerance, 129, and sensitive clone, 1215, to ESBVRD) in plantations in an area of Neossolo Flúvico (Fluvisol), sampled in the month of February, the initial phase of the anomaly, to 24 months of age in the municipality of Santana do Paraíso, MG, Brazil

\begin{tabular}{|c|c|c|c|c|}
\hline \multicolumn{2}{|c|}{ Leaf position } & \multicolumn{2}{|c|}{ Clone } & \multirow{2}{*}{ Significance } \\
\hline On the trunk & On the shoot & Sensitive (1215) & Intermediate tolerance (129) & \\
\hline & & 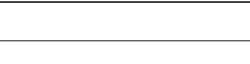 & $\mathrm{g} \mathrm{kg}^{-1}$ & \\
\hline \multirow[t]{3}{*}{ Lower third } & Base & 1241 & 272 & $* *$ \\
\hline & Middle & 916 & 260 & o \\
\hline & Tip & 867 & 135 & * \\
\hline \multirow[t]{3}{*}{ Middle third } & Base & 657 & 167 & $\mathrm{~ns}$ \\
\hline & Middle & 653 & 115 & $\mathrm{~ns}$ \\
\hline & Tip & 616 & 94 & $\mathrm{~ns}$ \\
\hline \multirow[t]{3}{*}{ Upper third } & Base & 682 & 116 & o \\
\hline & Middle & 656 & 135 & $\mathrm{~ns}$ \\
\hline & Tip & 529 & 111 & $\mathrm{~ns}$ \\
\hline
\end{tabular}

$* *, *{ }^{\circ},{ }^{n s}$ : significant at $1,5,10 \%$ and not significant up to $10 \%$, respectively, by the $\mathrm{F}$ test.

tissue, under the condition of high incidence of the anomaly, the contents found were 107 to $135 \mathrm{mg} \mathrm{kg}^{-1}$, and only 11 to $15 \mathrm{mg} \mathrm{kg}^{-1}$ in the woody trunk tissue of plants under the condition of low incidence of the anomaly (Table 6). These high contents in the woody trunk tissue under the condition of high incidence of the problem likely lead to greater expense on reagents during the whitening stage of the cellulose produced with this type of wood (Colodette, 2005).

Diagnosis of the nutritional state of leaves collected from two trees from different positions on the trunk and on the branches indicated that in the plants with ESBVRD, the Mn content was at a level considered as excessive by the DRIS (Diagnosis and Recommendation Integrated System) method (Beaufils, 1973). The values of the DRIS index for $\mathrm{Mn}$ of the leaf samples from the blight area ranged from 2.04 to 4.97 (all considered above normal, $>1.33$ ), indicating imbalance through excess and, in the area without blight, the values ranged from -1.09 to 1.54, characterizing situations of deficiency, normality and excess (values below normal, in the range of -1.33 to -0.66 ; normal, in the range of -0.67 to 0.67 ; and above normal, in the range of 0.68 to 1.33 ).

In plants of the area with ESBVRD, leaf biomass in the month of July $\left(1,008 \mathrm{~kg} \mathrm{ha}^{-1}\right)$ corresponded to $18 \%$ of the quantity of leaves found in the area without anomaly $\left(5,724 \mathrm{~kg} \mathrm{ha}^{-1}\right)$. However, the quantity of plant litter (basically composed of leaves) was $44 \%$ greater in the area with the anomaly $\left(8,083 \mathrm{~kg} \mathrm{ha}^{-1}\right)$ than in that without the anomaly $\left(5,614 \mathrm{~kg} \mathrm{ha}^{-1}\right)$. This situation indicates high leaf loss in the plants with the anomaly. The allocation of biomass among the components of the above ground part occurred in the following manner: $69 \%$ in the woody trunk tissue, $10 \%$ in the bark, $19 \%$ in the branches and $2 \%$ in the leaves in the plants with anomaly; and 70, 9, 13 and $8 \%$, respectively, in the woody trunk tissue, bark, branches and leaves in the plants without anomaly.

In anatomical evaluations of plant tissues in the eucalyptus clone sensitive to ESBVRD in the region of occurrence of the anomaly, the following symptoms were observed in leaves of plants with symptoms: hyperplasia, hypertrophy, accumulation of phenolic compounds, loss of turgidity, dehydration, drying out, protuberance outside the organ and wound periderm. Symptoms appear first on the abaxial surface of the leaf; on the petiole and stem, there was accumulation of phenolic compounds in the cortical region, in the phloem rays and in the xylem rays near the cambium. There was reduction and change in cambial activity, with production of anomalous xylem and phloem, periderm with intense shedding and greater accumulation of calcium oxalate crystals in vascular regions, such as the secondary phloem and leaf midrib.

In the analyses made in another step, when anatomical analysis of other tissues besides the leaves was made in a clone sensitive to ESBVRD (clone 386), with the anomaly, a distinct growth layer was observed, continuous in its entire diameter, with a particular structure and organization. In this growth layer, an abrupt transition is clear from a zone with fibers and axial parenchyma with finer walls and scarce pores (vessels) and of small diameter, to a zone with fibers and axial parenchyma with thicker walls and grouping of pores in a tangential strip. This abrupt transition of cellular organization and structure of the woody trunk tissue indicates abrupt variation in the usual cambium pattern, like a temporary paralysis in operation, followed by intense return to growth. One of the events that occurs during evolution of the ESBVRD is drying out of the tip of the shoots and the leaves, like a physiological pruning 
Table 6. Mn contents in components of the above ground part and roots in three diameter classes of eucalyptus plants (clone 386) under conditions of high and low incidence of ESBVRD, at a mutual distance of less than $150 \mathrm{~m}$, in the region of Belo Oriente at 24 months of age (sampling carried out in July, phase of strong symptoms), grown in a Neossolo Flúvico (Fluvisol) on the same hillside

\begin{tabular}{|c|c|c|c|c|}
\hline \multirow{2}{*}{ Component } & \multirow{2}{*}{ Position on the plant } & \multicolumn{2}{|c|}{ Incidence of ESBVRD } & \multirow{2}{*}{ Significance } \\
\hline & & High & Low & \\
\hline & & $\longrightarrow$ & - & \\
\hline \multirow[t]{7}{*}{ Leaf } & Lower third (from base to middle of shoots) & 3077 & 722 & $* * *$ \\
\hline & Lower third (from middle to tip of shoots) & 3064 & 748 & $* * *$ \\
\hline & Middle third (from base to middle of shoots) & 2185 & 380 & $* * *$ \\
\hline & Middle third (from middle to tip of shoots) & 2271 & 309 & $* * *$ \\
\hline & Upper third (from base to middle of shoots) & 2232 & 346 & $* * *$ \\
\hline & Upper third (from middle to tip of shoots) & 1680 & 238 & $* * *$ \\
\hline & Tip & 1910 & 201 & $* * *$ \\
\hline Mean & & 2346 & 421 & \\
\hline \multirow[t]{6}{*}{ Branches } & Lower third (from base to middle of shoots) & 991 & 201 & $* * *$ \\
\hline & Lower third (from middle to tip of shoots) & 1208 & 227 & $* * *$ \\
\hline & Middle third (from base to middle of shoots) & 713 & 154 & $* *$ \\
\hline & Middle third (from middle to tip of shoots) & 844 & 158 & $* * *$ \\
\hline & Upper third (from base to middle of shoots) & 624 & 131 & $* *$ \\
\hline & Upper third (from middle to tip of shoots) & 692 & 91 & $* * *$ \\
\hline Mean & & 845 & 157 & \\
\hline \multirow[t]{3}{*}{ Wood } & Lower third of the trunk & 135 & 11 & $\mathrm{~ns}$ \\
\hline & Middle third of the trunk & 107 & 14 & $\mathrm{~ns}$ \\
\hline & Upper third of the trunk & 123 & 15 & $\mathrm{~ns}$ \\
\hline Mean & & 122 & 13 & \\
\hline \multirow[t]{3}{*}{ Bark } & Lower third of the trunk & 2734 & 889 & $* * *$ \\
\hline & Middle third of the trunk & 2598 & 644 & $* * *$ \\
\hline & Upper third of the trunk & 1899 & 468 & $* * *$ \\
\hline Mean & & 2510 & 666 & \\
\hline Plant Litter & & 2164 & 873 & $* * *$ \\
\hline Overall mean & & 1597 & 426 & \\
\hline Depth & $0-20 \mathrm{~cm}$ & & & \\
\hline \multirow[t]{7}{*}{ Root } & Fine & 444 & 86 & $*$ \\
\hline & Medium & 374 & 49 & o \\
\hline & Thick & 216 & 41 & $\mathrm{~ns}$ \\
\hline & $80-100 \mathrm{~cm}$ & & & \\
\hline & Fine & 329 & 31 & $\mathrm{~ns}$ \\
\hline & Medium & 299 & 42 & $\mathrm{~ns}$ \\
\hline & Thick & 265 & 39 & $\mathrm{~ns}$ \\
\hline Mean & & 321 & 48 & \\
\hline Overall mean & ve ground part+root) & 959 & 237 & \\
\hline
\end{tabular}

o,$* ; *, * * *$ significant at $10,5,1$ and $0.1 \%$, respectively, and $\mathrm{ns}$ : not significant by the $\mathrm{F}$ test.

and, probably, with reflection in cambium activity (Figure 3).

Young healthy stems exhibit a well-defined vascular cambium, externally delimited by the secondary phloem and, internally, by the secondary xylem (Figure 3a). Cambium activity is altered in regions near the lesions, which may be seen by the formation of secondary xylem fascicles without characteristic vessel elements (Figure $3 b, d, e$ ), and with a heterogeneous lignification pattern of the cell walls in different regions of the woody trunk tissue (Figure 3c,e), and more accentuated in the region of the middle lamella. The secondary phloem usually accumulates phenolic compounds and rhombohedral crystals of calcium oxalate in the ray cells, but the accumulation of phenolic compounds extends to the cambium cells and intensifies with the evolution of the lesions (Figure 3e). 
Lesions in petioles begin in the epidermal and cortical region, and only in more advanced stages are significant alterations observed in the organization of vascular tissues. Lesions in the cortical region are characterized by hypertrophy, hyperplasia and cell phenolization.

Histological alterations in the leaf blade always begin near the epidermis, with an increase in the number (hyperplasia) and size (hypertrophy) of the mesophyll cells (Figure 4). The sponge parenchyma, which initially exhibits laxity (Figure 4a), with many intercellular spaces, becomes compact, with inconspicuous intercellular spaces (Figure 4b). The palisade parenchyma, which has a more compact arrangement, also undergoes cellular hyperplasia and

Table 7. Mn contents in leaves and branches (clone 386) collected in areas with high and low incidence of ESBVRD in the period of large occurrence of the anomaly (July 23,2009$)$ and in the recovery period (October 8,2009 ) grown in a Neossolo Flúvico (Fluvisol) on the same hillside

\begin{tabular}{llrr}
\hline \multirow{2}{*}{ Component } & Period & \multicolumn{2}{c}{ Incidence } \\
\cline { 3 - 4 } & & High & Low \\
\hline \multirow{2}{*}{ Leaf } & & \multicolumn{2}{c}{$\mathrm{mg} \mathrm{kg}^{-1}-$} \\
& Occurrence & 2195 & 309 \\
Branch & Recovery & 848 & 242 \\
& Occurrence & 845 & 169 \\
Overall mean & Recovery & 680 & 110 \\
\hline
\end{tabular}

hypertrophy, just as the other non-lignified cells of the mesophyll. The material of the secretory cavities is generally consumed in this stage. At more advanced stages, the entire mesophyll accumulates a large quantity of phenolic compounds (Figure 4c), which may be observed by the greenish coloring with toluidine blue. Finally, there is loss of cellular turgidity and collapse of the cells of the entire leaf blade (Figure 4d).

There is accumulation of phenolic compounds in tissues of the above ground part of plants with ESBVRD. The presence of these compounds is one of the symptoms of Mn toxicity in plants (Zornoza et al., 2010). In addition to this symptom, other symptoms related to situations of Mn toxicity, such as browncolored lesions (Wissemeier \& Horst, 1992), loss of apical dominance, shriveling of leaves (El-Jaoual \& Cox, 1998; Marschner, 2012) and splitting of lateral shoots, are also frequently found in plants with ESBVRD.

\section{CONCLUSIONS}

1. The hypoxia condition in locations where ESBVRD occurs in a more frequent and intense manner is more favorable to the presence of high $\mathrm{Mn}$ availability in the soil.

2. Manganese uptake is greater in clones sensitive to ESBVRD than in more tolerant clones.

3. Manganese leaf contents considered as excessive are observed in the same periods in which ESBVRD symptoms are considered to be more intense. In what is considered as the plant recovery period, a steep decline in Mn leaf contents is observed.

Table 8. Nutrient content in tissues of the above ground part of eucalyptus plants (clone 386) and in the plant litter in areas with (W) and without (WO) symptoms of ESBVRD

\begin{tabular}{|c|c|c|c|c|c|c|c|c|c|c|c|c|}
\hline \multirow{3}{*}{ Nutrient } & \multicolumn{12}{|c|}{ Component } \\
\hline & \multicolumn{2}{|c|}{ Leaf } & \multicolumn{2}{|c|}{ Branch } & \multicolumn{2}{|c|}{ Bark } & \multicolumn{2}{|c|}{ Wood } & \multicolumn{2}{|c|}{ Plant litter } & \multicolumn{2}{|c|}{$\begin{array}{l}\text { Above ground } \\
\text { part + plant litte }\end{array}$} \\
\hline & W & WO & W & WO & W & WO & W & WO & W & WO & W & Wo \\
\hline & & & & & & & $\mathrm{kg} \mathrm{ha}$ & & & & & \\
\hline $\mathrm{N}$ & 17.5 & 118.4 & 57.3 & 44.8 & 28.3 & 29.5 & 92.0 & 97.3 & 134.9 & 57.7 & 330.1 & 347.7 \\
\hline $\mathrm{P}$ & 1.4 & 7.1 & 14.6 & 6.1 & 7.5 & 4.9 & 9.8 & 10.1 & 6.5 & 3.2 & 39.7 & 31.4 \\
\hline $\mathrm{K}$ & 8.9 & 45.6 & 67.7 & 43.4 & 44.5 & 35.2 & 62.9 & 64.7 & 34.1 & 22.5 & 184.0 & 211.4 \\
\hline $\mathrm{Ca}$ & 7.8 & 29.5 & 51.9 & 44.9 & 98.2 & 120.6 & 21.6 & 27.7 & 56.3 & 55.0 & 235.7 & 277.6 \\
\hline $\mathrm{Mg}$ & 1.5 & 9.6 & 7.9 & 3.8 & 11.3 & 11.1 & 7.6 & 8.6 & 10.3 & 7.6 & 38.6 & 40.7 \\
\hline \multirow[t]{2}{*}{$\mathrm{S}$} & 2.8 & 14.0 & 8.3 & 5.4 & 4.6 & 3.4 & 36.7 & 33.0 & 17.8 & 10.7 & 70.2 & 66.6 \\
\hline & & & & & & & $\mathrm{g} \mathrm{ha}^{-1}$ & & & & & \\
\hline $\mathrm{Zn}$ & 0.02 & 0.06 & 0.10 & 0.05 & 0.04 & 0.02 & 0.51 & 0.49 & 0.14 & 0.06 & 0.81 & 0.68 \\
\hline $\mathrm{Cu}$ & 0.01 & 0.03 & 0.10 & 0.05 & 0.02 & 0.01 & 0.04 & 0.01 & 0.05 & 0.01 & 0.22 & 0.11 \\
\hline $\mathrm{Fe}$ & 0.26 & 0.63 & 2.19 & 1.27 & 0.15 & 0.13 & 1.40 & 4.37 & 3.74 & 2.03 & 7.7 & 8.4 \\
\hline $\mathrm{Mn}$ & 2.36 & 2.41 & 7.96 & 1.58 & 12.4 & 4.52 & 4.19 & 0.69 & 17.49 & 4.90 & 44.4 & 14.1 \\
\hline B & 0.04 & 0.18 & 0.08 & 0.10 & 0.05 & 0.07 & 0.07 & 0.30 & 0.24 & 0.27 & 0.48 & 0.92 \\
\hline
\end{tabular}



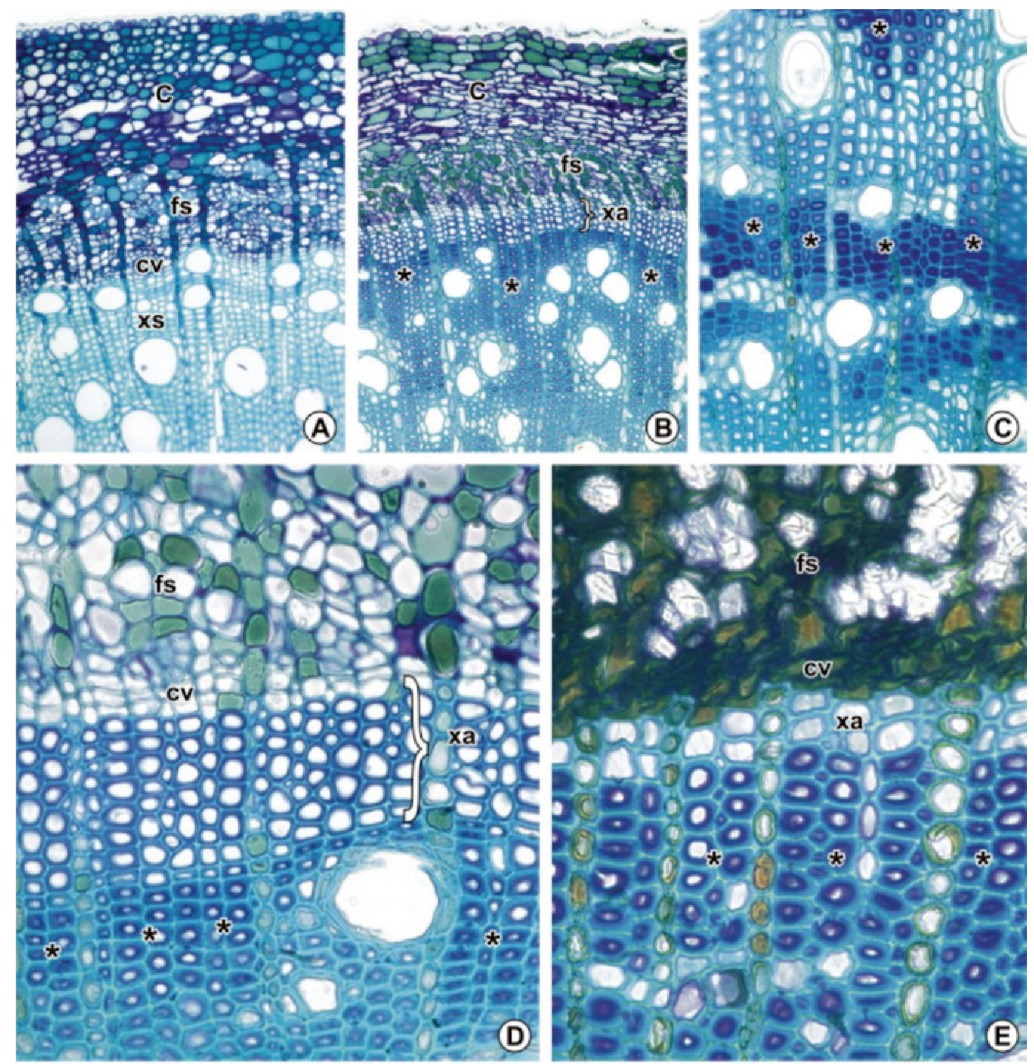

Figure 3. Cross-sections of young portions of the healthy stem of clone 386 (a) and with lesions from ESBVRD (b-e). (a) general appearance of the bark and of the wood of the healthy stem; (b) general appearance of the bark and of the wood with anomalous xylem fascicle; (c) detail of the wood with irregular lignification pattern; (d) detail of the previous figure; and (e) stage when the entire cambium region and the secondary phloem are completely phenolized and collapsed.

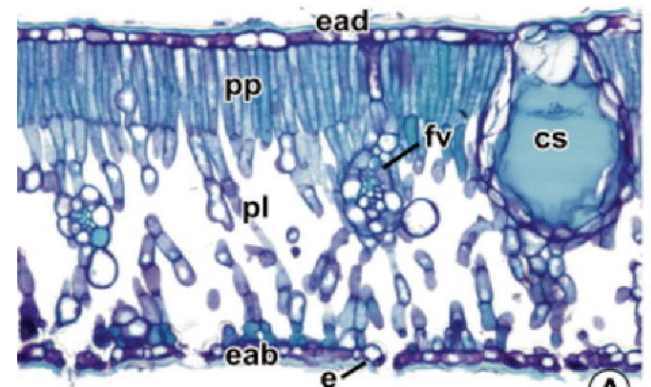

(A)

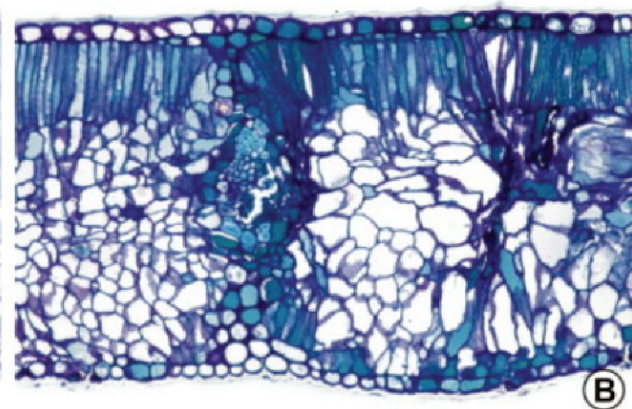

(B)

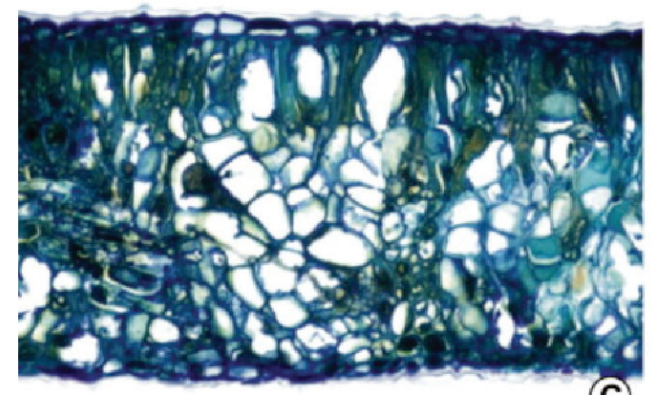

(C)

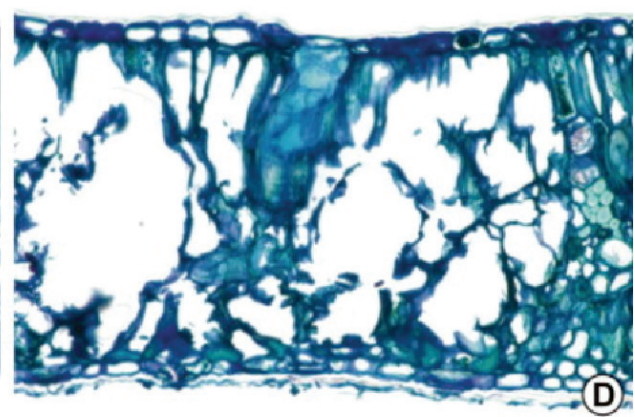

Figure 4. Cross-sections of the leaf blade of healthy clone 386 (a) and with lesions from ESBVRD (b-d). (a) overall appearance of the healthy interveinal region; (b) hyperplasia and hypertrophy of the mesophyll; (c) phenolization of the mesophyll; and (d) generalized cellular collapse. 
4. The greatest anatomical alterations in tissues of plants with ESBVRD are accompanied by accumulation of phenolic compounds, indicative of plants subjected to Mn toxicity.

\section{ACKNOWLEDGMENTS}

The authors thank the Fundação de Amparo à Pesquisa do Estado de Minas Gerais - FAPEMIG for granting a post-doctoral fellowship to Ecila Mercês de Albuquerque Villani (Processo CAG-21006/09).

\section{LITERATURE CITED}

ABREU, C.A.; LOPES, A.S. \& SANTOS, G. Micronutrientes. In: NOVAIS, R.F.; ALVAREZ V., V.H.; BARROS, N.F.; FONTES, R.L.F.; CANTARUTTI, R.B. \& NEVES, J.C.L., eds. Fertilidade do solo. Viçosa, MG: Sociedade Brasileira de Ciência do Solo, 2007. p. 645-736.

ALVAREZ V., V.H.; NOVAIS, R.F.; DIAS, L.E. \& OLIVEIRA, J.A. Determinação e uso do fósforo remanescente. Bol. Inf. Soc. Bras. Ci. Solo, 25:27-32, 2000.

BEAUFILS, E.R. Diagnosis and recommendation integrated system (DRIS). Natal, University Natal, 1973. 130p. (Soil Sci. Bull., 1)

COLMER, T.D. \& VOESENEK, L.A.C.J. Flooding tolerance: suites of plant traits in variable environments. Func. Plant Biol., 36:665-681, 2009.

COLODETTE, J.L. Tecnologia de Celulose e Papel. In: COLODETTE, J.L., org. Química da Madeira. UFV, 2005. s.p.

DAT, J.F.; CAPELLI, N.; FOLZER, H.; BOURGEADE, P. \& BADOT, P.-M. Sensing and signalling during plant flooding. Plant Physiol. Biochem., 42:273-282, 2004.

DIANESE, J.C.; HARIDASAN, M. \& MORAES, T.S.A. Tolerance to "Mal do Rio Doce", a major disease of Eucalyptus in Brazil. Trop. Pest. Manage., 30: 247-252, 1984.

DOUGHTY, R.W. The Eucalyptus: a natural and commercial history of the gum tree. The Johns Hopkins University Press, Baltimore, 2000. 237p.

EL-JAOUAL, T. \& COX, D.A. Manganese toxicity in plants. J. Plant Nutr., 21:353-386, 1998.

EMPRESA BRASILEIRA DE PESQUISA AGROPECUÁRIA EMBRAPA. Centro Nacional de Pesquisa do Solo. Manual de métodos de análise de solos. Rio de Janeiro, 1997. 212p.

ERNANI, P.R. Sintoma de toxidez de manganês em macieira. 2009. Available at: <http://sbcs.solos.ufv.br/solos/visao/ verDetalheMaterial.php? material=11>. Accessed in: Oct. 2010.

FERREIRA, F.A. Principais doenças do eucalipto no Estado de Minas Gerais. Belo Horizonte, EPAMIG, 1986. 32p. (Boletim Técnico, 23)
GONÇALVES, J.L.M. \& VALERI, S.V. Eucalipto e Pinus. In: FERREIRA, M.E.; CRUZ, M.C.P.; RAIJ, B.van \& ABREU, C.A., eds. Micronutrientes e elementos tóxicos na agricultura. Jaboticabal: CNPq/Fapesp/Potafos, 2001. p.393-423.

HAUCK, M.; PAUL, A.; GROSS, S. \& RAUBUCH, M. Manganese toxicity in epiphytic lichens: chlorophyll degradation and interaction with iron and phosphorus. Environ. Exp. Bot., 49:181-191, 2003.

HINCKLEY, T.M.; RICHTER, H. \& SCHULTE, P.J. Water relations. In: RAGHAVENDRA, A.S., ed. Physiology of trees. New York: Wiley Interscience, 1991. p.137-162.

JOHANSEN, D.A. Plant microtechnique. New York: McGrawHill Book Co. Inc., 1940. 423p.

LACERDA, F.J.P.; SILVA, I.R.; JESUS, G.J.; LEITE, F.P. \& MILAGRES, J.J.M. Comportamento de clones de eucalipto com tolerância diferencial à Seca do Ponteiro do Vale do Rio Doce em solução nutritiva com doses crescentes de manganês. In: REUNIÃO BRASILEIRA DE FERTILIDADE DO SOLO E NUTRIÇÃO DE PLANTAS, 29., 2010. FERTBIO, Guarapari, ES, 2010. CD-ROM

MARSCHNER, H. Mineral nutrition of higher plants. London: Academic Press, 2012. 889p.

MOU, D.; YAO, Y.; YANG, Y.; ZHANG, Y.; TIAN, C. \& ACHAL, V. Plant high tolerance to excess manganese related with root growth, manganese distribution and antioxidative enzyme activity in three grape cultivars. Ecotoxicol. Environ. Safety, 74:776-786, 2011.

NELSON, D.W. \& SOMMERS, L.E. Determination of total nitrogen in plant material. Agron. J., 65:109-12, 1973.

O'BRIEN, T.P.; FEDER, N. \& McCULLY, M.E. Polychromatic staining of plant cell walls by toluidine blue. Protoplasma, 59:368-373, 1964.

SHENKER, M.; PLESSNER, O.E. \& TEL-OR, E. Manganese nutrition effects on tomato growth, chlorophyll concentration, and superoxide dismutase activity. J. Plant Physiol., 161:197-202, 2004.

SOUSA, R.O.; VAHL, L.C. \& OTERO, X.L. Química de solos alagados. In: MELO, V.F. \& ALLEONI, L.R.F., eds. Química e mineralogia do solo. Parte II - Aplicações. Viçosa, MG: Sociedade Brasileira de Ciência do Solo, 2009. p.485-528.

STATSOFT. Statistica - Data analysis software system, version 11, 2012. Available at: <http://www.statsoft.com>. Accessed on: Sept. 15, 2012.

VITTI, G.C.; FERREIRA, A.C. \& MANARIN, C.A. Métodos de análises de elementos em material vegetal. Piracicaba, Escola Superior de Agricultura Luiz de Queiroz, 1997. 28p.

ZORNOZA, P.; SÁNCHEZ-PARDO, B. \& CARPENA, R.O. Interaction and accumulation of manganese and cadmium in the manganese accumulator Lupinus albus. J. Plant Physiol., 167:1027-1032, 2010.

WANG, H.-H.; FENG T.; PENG X.-X.; YAN M.-L.I; ZHOU P.L. \& TANG X.-K. Ameliorative effects of brassinosteroid on excess manganese-induced oxidative stress in Zea mays L. leaves. Agric. Sci. China, 8:1063-1074, 2009.

WISSEMEIER, A.H. \& HORST, W.J. Effect of light intensity on manganese toxicity symptoms and callose formation in cowpea (Vigna unguiculata (L.) Walp.). Plant Soil, 143:299-309, 1992. 